UDK $577.1: 61$

ISSN 1452-8258

J Med Biochem 38: 118-125, 2019

\title{
SERUM LACTATE AS RELIABLE BIOMARKER OF ACUTE KIDNEY INJURY IN LOW-RISK CARDIAC SURGERY PATIENTS
}

\section{SERUMSKI LAKTAT KAO POUZDAN BIOMARKER AKUTNOG OŠTEĆENJA BUBREGA KOD NISKORIZIČNIH KARDIOHIRURŠKIH BOLESNIKA}

\author{
Mina Radovic ${ }^{1}$, Suzana Bojic ${ }^{2,3}$, Jelena Kotur-Stevuljevic ${ }^{4}$, Visnja Lezaic ${ }^{2,5}$, Biljana Milicic ${ }^{6}$, \\ Milos Velinovic ${ }^{2,7}$, Radmila Karan 1,2, Sanja Simic-Ogrizovic ${ }^{2,5}$ \\ ${ }^{1}$ Department of Anaesthesiology and Intensive Care, Clinic for Cardiac Surgery, \\ Clinical Centre of Serbia, Belgrade, Serbia \\ ${ }^{2}$ School of Medicine, University of Belgrade, Belgrade, Serbia \\ ${ }^{3}$ Department of Anaesthesiology and Intensive Care, CHC Bezanijska kosa, Belgrade, Serbia \\ ${ }^{4}$ Department of Medical Biochemistry, Faculty of Pharmacy, Belgrade, Serbia \\ ${ }^{5}$ Department of Nephrology, Institute for Nephrology, Clinical Centre of Serbia, Belgrade, Serbia \\ ${ }^{6}$ Department of Statistics, Faculty of Stomatology, University of Belgrade, Belgrade, Serbia \\ ${ }^{7}$ Department of Cardiac Surgery, Clinic for Cardiac Surgery, Clinical Centre of Serbia, Belgrade, Serbia
}

\section{Summary}

Background: Cardiac surgery-associated acute kidney injury (CSA-AKI) frequently occurs in patients assessed as low-risk for developing CSA-AKI. Neutrophil GelatinaseAssociated Lipocalin (NGAL), Kidney Injury Molecule-1 $(\mathrm{KIM}-1)$ and lactate are promising biomarkers of CSA-AKI but have not yet been explored in low-risk patients.

Aim: To evaluate urinary NGAL (UNGAL), KIM-1 and lactate as biomarkers of CSA-AKI in patients with low-risk for developing CSA-AKI.

Methods: This prospective, observational study included 100 adult elective cardiac surgery patients assessed as lowrisk for developing CSA-AKI. UNGAL, KIM-1 and lactate were measured preoperatively, at the end of cardiopulmonary bypass (CPB) and 3, 12, 24 and $48 \mathrm{~h}$ later.

Results: Fifteen patients developed CSA-AKI. Patients with CSA-AKI had significantly higher lactate but similar UNGAL and KIM-1 levels compared to patients without CSA-AKI. Unlike UNGAL and KIM-1, postoperative lactate was good biomarker of CSA-AKI with the highest odds ratio (OR) 2.7 [1.4-4.9] $24 \mathrm{~h}$ after CPB. Peak lactate concentration $\geq 4$

\section{Kratak sadržaj}

Uvod: Akutno oštećenje bubrega nakon kardiohirurških procedura (KH-AOB) nastaje često i kod bolesnika koji su ocenjeni kao niskorizični za nastanak KH-AOB. Neutrofilna želatinaza udružena sa lipokalinom (NGAL), bubrežni štetni molekul-1 (KIM-1) i laktat su novi biomarkeri KH-AOB ali do sada nisu ispitivani kod niskorizičnih bolesnika.

Cilj: Ispitati urinarni NGAL (uNGAL), KIM-1 i laktat kao biomarkere $\mathrm{KH}-\mathrm{AOB}$ kod bolesnika koji su ocenjeni kao niskorizični za nastanak $\mathrm{KH}-\mathrm{AOB}$.

Metode: Ovom prospektivnom opservacionom studijom obuhvaćeno je 100 odraslih elektivnih kardiohirurških bolesnika koji su ocenjeni kao niskorizični za razvoj $\mathrm{KH}-\mathrm{AOB}$. UNGAL, KIM-1 i laktat su određivani preoperativno, na kraju kardiopulmonalnog bajpasa (KPB) kao i 3, 12, 24 i 48 sati kasnije. Rezultati: KH-AOB se razvilo kod 15 bolesnika. Bolesnici sa $\mathrm{KH}-\mathrm{AOB}$ su imali značajno više vrednosti lakatata ali slične vrednosti uNGAL i KIM-1 u poređenju sa bolesnicima bez KH-AOB. Za razliku od UNGAL i KIM-1, vrednost lakatata posle operacije se pokazala kao pouzdan biomarker KH-AOB sa najvišim OR $2.7[1,4-4,9] 24$ sata nakon završetka KPB
Address for correspondence:

Suzana Bojic

CHC Bezanijska kosa, Bezanijska kosa bb,

11000 Belgrade, Serbia

e-mail: subojic@yahoo.com
List of abbreviations: BMI, Body mass index; CABG, Coronary artery bypass graft; CPB, Cardiopulmonary bypass; CSA-AKI, Cardiac surgery-associated cute kidney injury; KIM-1, Kidney Injury Molecule-1; uNGAL, Urinary Neutrophil GelatinaseAssociated Lipocalin. 
$\mathrm{mmol} / \mathrm{L}$ carried dramatically higher risk for developing CSA-AKI (OR 6.3 [1.9-20.5]).

Conclusions: Unlike uNGAL and KIM-1, postoperative lactate was significant independent predictor of CSA-AKI with the highest odds ratio $24 \mathrm{~h}$ after CPB.

Keywords: acute kidney injury, cardiac surgery, Kidney Injury Molecule-1, lactate, Neutrophil Gelatinase-Associated Lipocalin

\section{Introduction}

Cardiac surgery carries a greater risk for perioperative acute kidney injury (AKI) than any other type of surgery (1). Cardiac surgery-associated AKI (CSAAKI) occurs in approximately $22 \%$ of cardiac surgery patients and is linked to a 5 -fold increase in mortality (2-4). Given the limited prevention and treatment strategies, recognition of patients at risk for development of CSA-AKI is of paramount importance. Risk assessment has, so far, been restricted to risk scores, and, arguably, novel biomarkers of AKI.

The best validated risk scores (5-7) are focused on predicting severe CSA-AKI requiring dialysis although mild CSA-AKI is far more likely to occur (3). The only scoring system designed to predict all stage CSA-AKI is Leicester Cardiac Surgery Research AKI Risk Score (8) but it still needs an external validation. It is very important to acknowledge that CSA-AKI could also occur in patients that are assessed as lowrisk by available scores.

Novel biomarkers such as Neutrophil Gelatinase-Associated Lipocalin (NGAL) and Kidney Injury Molecule-1 (KIM-1) have been studied as potential biomarkers of CSA-AKI with conflicting results (9, 10). High costs, absence of clear recommendations as well as difficult interpretation are preventing their routine use.

Lactate is routinely measured biomarker of tissue hypoperfusion. Hyperlactatemia is common in cardiac surgery especially if cardiopulmonary bypass (CPB) is employed (11). Its association with increased morbidity and mortality is well known (12-15) but only few recent studies suggested that it might be linked to development of CSA-AKI $(13,14,16,17)$.

We aimed to evaluate urinary NGAL (uNGAL), $\mathrm{KIM}-1$ and lactate concentrations as biomarkers of CSA-AKI in patients undergoing elective cardiac surgery that are assessed as low-risk for development of CSA-AKI.

\section{Materials and Methods}

This prospective observational study was conducted at the tertiary level adult cardiac surgery university hospital. The study was approved by the
Vrednosti lakatata $\geq 4 \mathrm{mmol} / \mathrm{L}$ su bile povezane sa dramatično povišenim rizikom za nastanak KH-AOB (OR 6,3 $[1,9-20,5])$.

Zaključak: Za razliku od uNGAL i KIM-1, vrednosti lakata posle operacije su bile značajan nezavisni prediktor razvoja $\mathrm{KH}-\mathrm{AOB}$ sa najboljom prediktivnom vrednošću 24 sata nakon završetka KPB.

Ključne reči: akutno oštećenje bubrega, kardiohirurgija, bubrežni štetni molekul-1, laktat, neutrofilna želatinaza udružena sa lipokalinom

institutional Ethical Committee and performed in conformance with the Declaration of Helsinki ethical guidelines. All patients included in this study signed an informed consent form.

\section{Patients}

A total of 100 adult consecutive consenting patients fulfilling study criteria were recruited. Inclusion criteria were age $\geq 18$ years, elective cardiac surgery with cardiopulmonary CPB including coronary artery bypass grafting (CABG), valve surgery or combined $C A B G$ and valve surgery, normal preoperative kidney function and low risk for developing CSAAKI. Exclusion criteria were age $<18$ years, emergency or redo surgery, preoperative AKI or chronic kidney disease and medium or high risk for developing of CSA-AKI. Kidney function was considered normal if eGFR estimated by Modification of Diet in Renal Disease (MDRD) study equation (18) was > 60 $\mathrm{ml} / \mathrm{min}$ per $1.73 \mathrm{~m}^{2}(19)$. Risk for developing of CSAAKI was assessed according to Cleveland Clinic Score (5). Patients with Cleveland Clinic Score $\leq 5$ are considered to be at low risk for developing CSA-AKI. CSA-AKI was diagnosed according to Kidney Disease: Improving Global Outcomes (KDIGO) criteria (20). Rapid reversal CSA-AKI was defined by an episode of $A K I$ that lasts $\leq 48 \mathrm{~h}$ or less and acute kidney disease (AKD) by duration of $A K I \geq 7$ days (21). All patients received routine perioperative care.

Age, gender, type of surgery, duration of CPB, duration of aortic cross-clamping, intraoperative blood loss and intraoperative blood transfusion were recorded. Body mass index (BMI) was calculated based on anthropometric evaluation (weight, height). Leicester Cardiac Surgery Research AKI Risk Score in which percent value presents probability for CSA-AKI development was also calculated (8).

\section{Samples}

Arterial blood and urine samples were collected simultaneously at predetermined time-points: preoperatively (before the induction of anaesthesia), immediately after the end of CPB and 3, 12, 24 and 48 hours after the end of CPB. Lactate levels were meas- 
ured immediately after collection using blood gas analyzer Gem Premier 3000, Instrumentation Laboratory, Milano, Italy. Serum creatinine levels were measured on the day of collection employing routine laboratory method (AU680, Beckman Coulter, USA). Urine samples were centrifuged and stored at -80C until further analysis. Urine NGAL and KIM-1 levels were measured using Enzyme-linked Immunosorbent Assay (ELISA) method (ABBOTT Diagnostics, IL, USA and R\&D Systems Inc, MN, USA, respectively).

\section{Statistical analysis}

Statistical analysis was performed in SPSS Statistics Version 25 software (SPSS Inc., Chicago, IL, USA). The normality of data was assessed with Kolmogorov-Smirnov test. The data are presented as median and $25^{\text {th }}$ to $75^{\text {th }}$ quartile or frequencies. The differences between the groups were compared using the Mann-Whitney U or Chi square test, where appropriate. The within-group variations were analyzed using the Friedman's test. A univariate binary logistic regression analysis was employed to test possible predictors of CSA-AKI. The significance level for all statistical tests was set at 0.05 .

\section{Results}

In our study, 15 out of 100 low-risk cardiac surgery patients developed CSA-AKI. Twelve of CSA-AKI patients had rapid reversal $A K I$ (stage 1 according to KDIGO definition) and 3 had AKD (stage 2 according to KDIGO definition).

Baseline characteristics of the patient groups are shown in Table I. Statistically significant difference between patients with and without CSA-AKI in age, gender, BMI, type of surgery, intraoperative blood loss and transfusion was not found. As expected from the study design, patients with and without CSA-AKI had similar Cleveland Clinic Scores but patients with CSAAKI had significantly higher risk for developing CSA-

Table I Comparison of the baseline characteristics of the patients with and without CSA-AKI.

\begin{tabular}{|l|c|c|c|c|}
\hline & Overall $(\mathrm{n}=100)$ & $\begin{array}{c}\text { Without CSA-AKI } \\
(\mathrm{n}=85)\end{array}$ & $\begin{array}{c}\text { With CSA-AKI } \\
(\mathrm{n}=15)\end{array}$ & $p$ \\
\hline Age (years) & $63.0[56.25-69.0]$ & $63.0[57.0-68.5]$ & $68.0[60.0-73.0]$ & 0.087 \\
\hline Gender (male/female) & $77 / 23$ & $66 / 19$ & $11 / 4$ & 0.714 \\
\hline BMI (kg/m²) & $27.5[25.4-29.4]$ & $27.3[25.4-29.4]$ & $28.1[26.0-29.3]$ & 0.612 \\
\hline Surgery (valve/CABG/valve + CABG) & $21 / 75 / 4$ & $18 / 65 / 2$ & $3 / 10 / 2$ & 0.134 \\
\hline Duration of CPB (min) & $80.0[64.0-97.7]$ & $75.0[59.5-93.0]$ & $101.0[74.0-110.0]$ & 0.012 \\
\hline Duration of aortic cross-clamping (min) & $44.5[30.0-60.0]$ & $40[29.5-52.0]$ & $55.0[39.0-71.0]$ & 0.024 \\
\hline Intraoperative blood loss (mL) & $1200[1000-1575]$ & $1200[1000-1500]$ & $1400[1200-2000]$ & 0.052 \\
\hline Intraoperative transfusion (mL) & $470[415-590]$ & $450[405-565]$ & $576[430-714]$ & 0.082 \\
\hline Hospitalisation (days) & $6[5-7]$ & $6[6-7]$ & $7[6-12]$ & 0.017 \\
\hline Cleveland Clinic Score (0/1/2) & $39 / 22 / 19$ & $35 / 17 / 17$ & $4 / 4 / 3$ & 0.514 \\
\hline $\begin{array}{l}\text { Leicester Cardiac Surgery Research } \\
\text { AKI Risk Score (\%) }\end{array}$ & $11.51[8.44-15.96]$ & $11.41[7.41-15.23]$ & $15.17[11.24-19.10]$ & 0.018 \\
\hline Baseline creatinine ( $\mu$ mol/L) & $74.0[65.0-83.0]$ & $71.0[64.5-80.5]$ & $89.0[70.0-96.0]$ & 0.025 \\
\hline Baseline eGFR (mL/min/1.73 m²) & $93.3[81.3-109.8]$ & $95.6[85.1-110.2]$ & $76.4[64.5-90.5]$ & 0.002 \\
\hline Lactate (mmol/L) & $1.30[1.00-1.70]$ & $1.3[1.0-1.6]$ & $1.2[0.9-1.8]$ & 0.656 \\
\hline uNGAL (ng/mL) & $3.12[0.39-11.78]$ & $3.52[0.51-12.36]$ & $2.36[0.25-6.02]$ & 0.457 \\
\hline KIM-1 (pg/mL) & $382.0[123.5-936.0]$ & $437.5[136.0-946.2]$ & $256.5[86.0-760.5]$ & 0.231 \\
\hline
\end{tabular}

Data are presented as median and interquartile range or frequencies. Mann-Whitney $U$ test, Chi-squire test. CSA-AKI - Cardiac surgery-associated cute kidney injury; BMI - Body mass index; eGFR - Estimated glomerular filtration rate; UNGAL - Urinary Neutrophil Gelatinase-Associated Lipocalin; KIM-1 - Kidney Injury Molecule-1; CABG - Coronary artery bypass graft; CPB Cardiopulmonary bypass. 

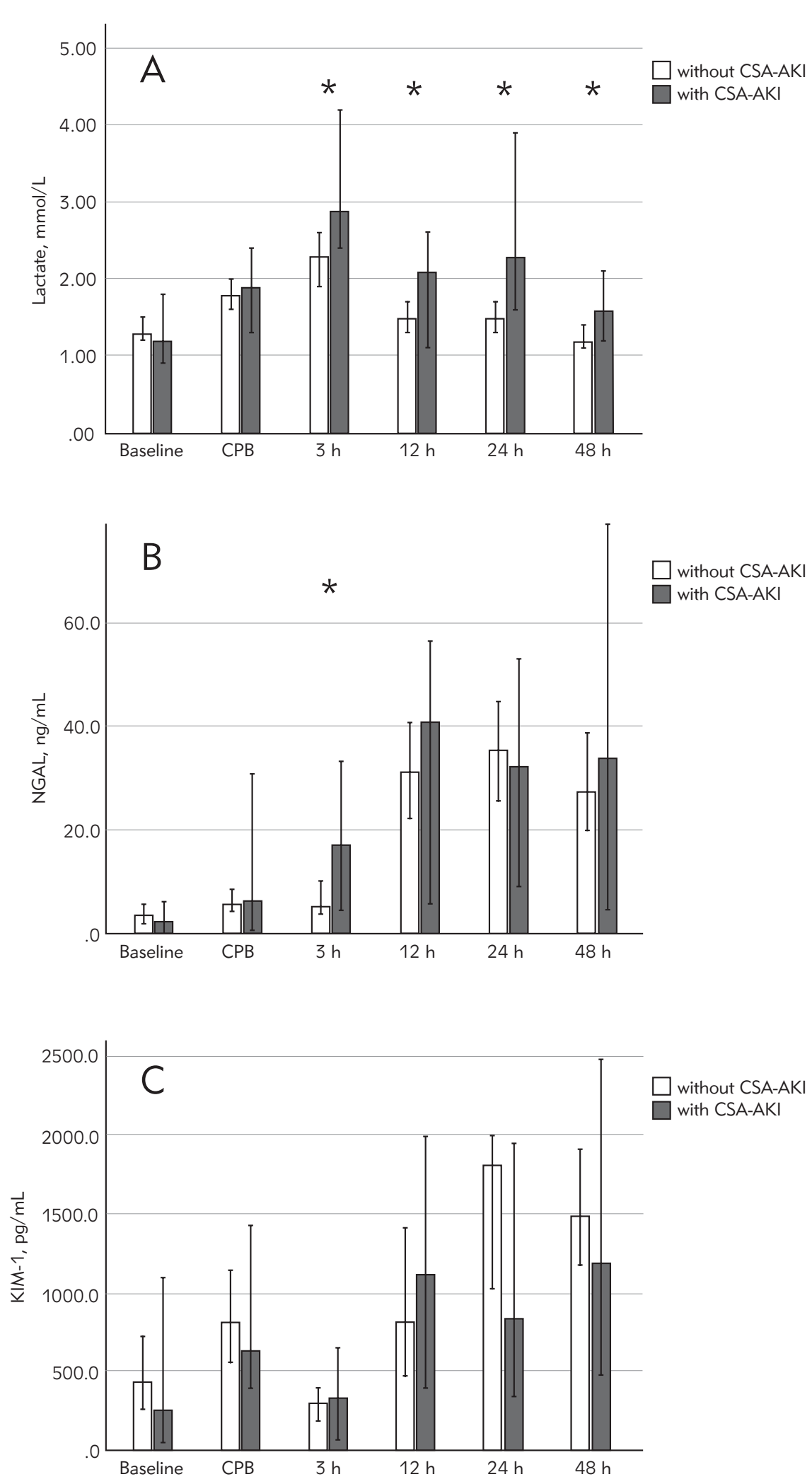

Figure 1 Serial (A) lactate, (B) uNGAL and (C) KIM-1 measurements in patients with and without CSA-AKI.

Data are presented as median and 95\% C.I. *Statistically significant difference $(p<0.05)$ between patients with and without CSAAKI at specified time point, Mann-Whitney U test. CSA-AKI - Cardiac surgery-associated acute kidney injury; uNGAL - Urinary Neutrophil Gelatinase-Associated Lipocalin; KIM-1 - Kidney Injury Molecule-1; CPB - Cardiopulmonary bypass. 
Table II A univariate binary logistic regression for prediction of CSA-AKI.

\begin{tabular}{|c|c|c|}
\hline & Odds Ratio [95\% C.I.] & $\mathrm{p}$ \\
\hline Creatinine (baseline) & $1.056[0.1 .013-0.101]$ & 0.009 \\
\hline eGFR (baseline) & $0.947[0.910-0.984]$ & 0.006 \\
\hline Cleveland Clinic Score & $1.164[0.600-2.258]$ & 0.653 \\
\hline Leicester Cardiac Surgery Research AKI Risk Score & $1.047[0.986-1.113]$ & 0.135 \\
\hline Duration of CPB & $1.016[1.000-1.032]$ & 0.048 \\
\hline Duration of aortic cross-clamping & $1.022[1.002-1.043]$ & 0.030 \\
\hline Lactate (baseline) & $0.664[0.204-2.159]$ & 0.496 \\
\hline Lactate (CPB) & $1.540[0.831-2.852]$ & 0.170 \\
\hline Lactate (3 h) & $1.410[1.022-1.944]$ & 0.036 \\
\hline Lactate (12 h) & $1.470[1.007-2.146]$ & 0.046 \\
\hline Lactate (24 h) & $2.721[1.485-4.986]$ & 0.001 \\
\hline Lactate (48 h) & $2.436[1.227-4.837]$ & 0.011 \\
\hline Lactate (CPB - baseline) & $1.936[0.981-3.821]$ & 0.057 \\
\hline Lactate (3h - baseline) & $1.443[1.034-2.015]$ & 0.031 \\
\hline Lactate (12 $\mathrm{h}$ - baseline) & $1.501[1.026-2.195]$ & 0.036 \\
\hline Lactate (24 $\mathrm{h}$ - baseline) & $2.569[1.460-4.546]$ & 0.001 \\
\hline Lactate (48 h - baseline) & $2.031[1.109-3.719]$ & 0.022 \\
\hline Lactate $(3 \mathrm{~h}-\mathrm{CPB})$ & $1.503[1.013-2.230]$ & 0.043 \\
\hline Lactate $(12 \mathrm{~h}-\mathrm{CPB})$ & $1.457[0.930-2.283]$ & 0.100 \\
\hline Lactate (24 h - CPB) & $2.173[1.224-3.585]$ & 0.008 \\
\hline Lactate (48 h - CPB) & $1.369[0.773-2.422]$ & 0.281 \\
\hline Lactate $(12 \mathrm{~h}-3 \mathrm{~h})$ & $0.891[0.604-1.313]$ & 0.559 \\
\hline Lactate $(24 \mathrm{~h}-3 \mathrm{~h})$ & $1.003[0.683-1.475]$ & 0.986 \\
\hline Lactate (48 h-3h) & $0.861[0.627-1.181]$ & 0.352 \\
\hline Lactate $(24 \mathrm{~h}-12 \mathrm{~h})$ & $1.310[0.725-2.368]$ & 0.371 \\
\hline Lactate (48 h - 12 h) & $0.890[0.598-1.325]$ & 0.566 \\
\hline Lactate $(48 \mathrm{~h}-24 \mathrm{~h})$ & $0.596[0.331-1.074]$ & 0.085 \\
\hline Peak lactate & $1.067[0.939-1.212]$ & 0.009 \\
\hline Peak lactate $\geq 4 \mathrm{mmol} / \mathrm{L}$ & $6.330[1.957-20.472]$ & 0.001 \\
\hline
\end{tabular}

Data are presented as odds ratio and 95\% C.I. Univariate binary logistic regression. CSA-AKI - Cardiac surgery-associated acute kidney injury; eGFR - Estimated glomerular filtration rate; CPB - Cardiopulmonary bypass.

AKI according to Leicester Cardiac Surgery Research AKI Risk Score. Although only patients with normal kidney function were included, patients that developed CSA-AKI had significantly higher creatinine levels but similar UNGAL and KIM-1 levels compared to patients without CSA-AKI. CSA-AKI patients also had longer hospitalization, CPB and aortic cross-clamping duration.
Figure 1 depicts serial measurements of lactate $(A)$, urinary NGAL (B) and KIM-1 (C) in patients with and without CSA-AKI. After the end of CPB, a significant increase in concentrations of all three biomarkers was noted ( $p<0.05$ for all timepoints, except for lactate at $48 \mathrm{~h}$ and $\mathrm{UNGAL}$ after completion of CPB). Compared to patients without CSA-AKI, patients with CSA-AKI had significantly higher lactate levels at all 
time point except at the CPB end. A significant difference in UNGAL and KIM-1 levels between patients with and without CSA-AKI was not found except for uNGAL $3 \mathrm{~h}$ after CPB.

A univariate binary logistic regression was performed in order to identify independent predictors of CSA-AKI (Table II). As expected, absolute lactate levels at 3, 12, 24 and $48 \mathrm{~h}$ after the end of CPB were independent predictors of CSA-AKI with highest odds ratio of 2.72 for lactate levels at $24 \mathrm{~h}$ after the end of CPB. Interestingly, the differences in lactate concentrations between various time points as well as peak lactate concentration had lower prediction value then the absolute lactate concentration. However, peak lactate $\geq 4 \mathrm{mmol} / \mathrm{L}$ was associated with 6.33 times higher probability for developing CSA-AKI. Baseline creatinine and eGFR as well as duration of CPB and aortic cross-clamping were also independent predictors of CSA-AKI.

\section{Discussion}

Most of the research on prediction of CSA-AKI is focused on identifying high-risk patients. However, CSA-AKI also occurs in patients that are classified as low-risk so it is reasonable to assume that certain risk factors are missed by available risk scores. To identify low-risk patients we used Cleveland Clinic Score. Cleveland Clinic Score is best validated but, effectively, predicts only severe CSA-AKI that requires dialysis (5). On the other hand, Leicester Cardiac Surgery Research Acute Kidney Injury Risk Score predicts any stage CSA$\mathrm{AKI}$ but has debatable application outside UK healthcare system (8). It is therefore not surprising that our patients with CSA-AKI had similar both Cleveland Clinic scores to patients without CSA-AKI (Table I).

As expected, a significant increase of $u N G A L$ and KIM-1 levels after CPB was observed (Figure $1 B$ and $1 C)$. An increase in UNGAL levels after CPB was already demonstrated in patients without CSA-AKI $(22,23)$ and could be a consequence of systemic inflammation caused by CPB. A significant difference in either UNGAL or KIM-1 levels between patients with and without CSA-AKI was not found which implies that both biomarkers have poor diagnostic and predictive value as previously reported (9, 10, 24-27). Bulluck at al. (28) demonstarted that preexisting chronic kidney disease (CKD) could also alter NGAL and KIM-1 levels and, consequently, affect their levels during and after surgery. Patients with preexisting CKD were excluded from our study.
In our study lactate concentrations significantly increased after the end of CPB and were significantly higher in patients with CSA-AKI (Figure 1A). Consequently, postoperative lactate was good predictor of CSA-AKI with the highest OR 2.7 for levels at $24 \mathrm{~h}$ after the end of CPB, close to previously reported (13). To our surprise, the differences in lactate concentrations between various time points had lower prediction value then the absolute lactate concentration (Table II). Mak et al. (13) found that persistent hyperlactatemia is more important determinant of postoperative outcome than the absolute lactate concentration but their study included patients at high risk for developing CSA-AKI and only those with lactate $\geq 3 \mathrm{mmol} / \mathrm{L}$. According to our results (Table II), low-risk patients with peak lactate concentration $\geq$ $4 \mathrm{mmol} / \mathrm{L}$ were 6.3 times more likely to develop CSAAKI similarly to findings of Naik et al. (14) although their study population included high-risk patients. Normalized lactate load (16), although more comprehensive, is labour intensive and, therefore, not very likely used by clinicians.

This study has numerous limitations including small number of patients, short observational period, infrequent sampling etc. Our results need to be confirmed by other researches with larger patient cohorts, patients with high risk for developing CSA$\mathrm{AKI}$ and also pediatric cardiac surgery patients.

\section{Conclusions}

Our results suggest that, as opposed to $u N G A L$ and $\mathrm{KIM}-\mathrm{a}$, absolute lactate levels could serve as reliable biomarkers of CSA-AKI even in cardiac surgery patients with low risk for developing CSA-AKI. Given the dramatic increase in CSA-AKI risk, a high level of vigilance for lactate concentrations $\geq 4 \mathrm{mmol} / \mathrm{L}$ should be maintained. Further investigations are needed to backup these conclusions.

Acknowledgements. This study was partially supported by a grant from the Ministry of Education, Science and Technological Development, Republic of Serbia, Project No. 175089.

\section{Conflict of interest statement}

The authors stated that they have no conflicts of interest regarding the publication of this article. 


\section{References}

1. Grams ME, Sang Y, Coresh J, Ballew S, Matsushita K, Molnar $M Z$, et al. Acute Kidney Injury After Major Surgery: A Retrospective Analysis of Veterans Health Administration Data. American journal of kidney diseases: the Official Journal of the National Kidney Foundation 2016; 67(6): 872-80.

2. Goren $\mathrm{O}$, Matot I. Perioperative acute kidney injury. British Journal of Anaesthesia 2015; 115: Suppl 2: ii3-14.

3. Hoste EAJ, Vandenberghe W. Epidemiology of cardiac surgery-associated acute kidney injury. Best practice \& research Clinical Anaesthesiology 2017; 31(3): 299_ 303.

4. O'Neal JB, Shaw AD, Billings FTT. Acute kidney injury following cardiac surgery: current understanding and future directions. Critical care (London, England) 2016; 20(1): 187.

5. Gungor BZ, Sipahioglu N, Sonmez H, Ekmekci H, Toprak S, Ayaz G, Gurel CB, Mutlu T, Ulutin T, Sipahioglu F, llerigelen $B$. Endothelial dysfunction markers in low cardiovascular risk individuals: comparison of males and females. J Med Biochem 2017; 36: 62-72.

6. Panjeta M, Tahirović I, Sofić E, Corić J, Dervišević A. Interpretation of erythropoietin and haemoglobin levels in patients with various stages of chronic kidney disease. J Med Biochem 2017; 36: 145-52.

7. Englberger L, Suri RM, Li Z, Dearani JA, Park SJ, Sundt TM, 3rd, et al. Validation of clinical scores predicting severe acute kidney injury after cardiac surgery. American Journal of Kidney Diseases: The Official Journal of the National Kidney Foundation 2010; 56(4): 623-31.

8. Birnie K, Verheyden V, Pagano D, Bhabra M, Tilling K, Sterne JA, et al. Predictive models for kidney disease: improving global outcomes (KDIGO) defined acute kidney injury in UK cardiac surgery. Critical Care (London, England) 2014; 18(6): 606.

9. Ho J, Tangri N, Komenda P, Kaushal A, Sood M, Brar R, et al. Urinary, Plasma, and Serum Biomarkers' Utility for Predicting Acute Kidney Injury Associated With Cardiac Surgery in Adults: A Meta-analysis. American Journal of Kidney Diseases: The Official Journal of the National Kidney Foundation 2015; 66(6): 993-1005.

10. Zhou F, Luo Q, Wang L, Han L. Diagnostic value of neutrophil gelatinase-associated lipocalin for early diagnosis of cardiac surgery-associated acute kidney injury: a meta-analysis. European Journal of Cardio-thoracic Surgery: Official Journal of the European Association for Cardio-Thoracic Surgery 2016; 49(3): 746-55.

11. Minton J, Sidebotham DA. Hyperlactatemia and Cardiac Surgery. The Journal of Extra-corporeal Technology 2017; 49(1): 7-15.

12. Song Y, Soh S, Shim JK, Park KU, Kwak YL. Skin perfusion pressure as an indicator of tissue perfusion in valvular heart surgery: Preliminary results from a prospective, observational study 2017; 12(9): e0184555.

13. Mak NT, lqbal S, de Varennes B, Khwaja K. Outcomes of post-cardiac surgery patients with persistent hyperlactatemia in the intensive care unit: a matched cohort study. Journal of Cardiothoracic Surgery 2016; 11: 33.
14. Naik R, George G, Karuppiah S, Philip MA. Hyperlactatemia in patients undergoing adult cardiac surgery under cardiopulmonary bypass: Causative factors and its effect on surgical outcome. Annals of Cardiac Anaesthesia 2016; 19(4): 668-75

15. Hajjar LA, Almeida JP, Fukushima JT, Rhodes A, Vincent $\mathrm{JL}$, Osawa EA, et al. High lactate levels are predictors of major complications after cardiac surgery. The Journal of Thoracic and Cardiovascular Surgery 2013; 146(2): 455-60.

16. Zhang Z, Ni H. Normalized lactate load is associated with development of acute kidney injury in patients who underwent cardiopulmonary bypass surgery. PloS one 2015; 10(3): e0120466.

17. Jorge-Monjas $P$, Bustamante-Munguira J, Lorenzo $M$, Heredia-Rodriguez M, Fierro I, Gomez-Sanchez E, et al. Predicting cardiac surgery-associated acute kidney injury: The CRATE score. Journal of Critical Care 2016; 31(1): 130-8.

18. Levey AS, Coresh J, Greene T, Stevens LA, Zhang YL, Hendriksen $S$, et al. Using standardized serum creatinine values in the modification of diet in renal disease study equation for estimating glomerular filtration rate. Annals of Internal Medicine 2006; 145(4): 247-54.

19. Zavada J, Hoste E, Cartin-Ceba R, Calzavacca P, Gajic O, Clermont $G$, et al. A comparison of three methods to estimate baseline creatinine for RIFLE classification. Nephrology, dialysis, transplantation : official publication of the European Dialysis and Transplant Association European Renal Association 2010; 25(12): 3911-8.

20. Khwaja A. KDIGO clinical practice guidelines for acute kidney injury. Nephron Clinical Practice 2012; 120(4): c179-84.

21. Chawla LS, Bellomo R, Bihorac A, Goldstein SL, Siew ED, Bagshaw SM, et al. Acute kidney disease and renal recovery: consensus report of the Acute Disease Quality Initiative (ADQI) 16 Workgroup. Nature Reviews Nephrology 2017; 13(4): 241-57.

22. Bataille A, Tiepolo A, Robert T, Boutten A, Longrois D, Dehoux $M$, et al. Reference change values of plasma and urine NGAL in cardiac surgery with cardiopulmonary bypass. Clinical Biochemistry 2017; 50(18): 1098-103.

23. de Geus HR, Ronco C, Haase M, Jacob L, Lewington A, Vincent JL. The cardiac surgery-associated neutrophil gelatinase-associated lipocalin (CSA-NGAL) score: A potential tool to monitor acute tubular damage. The Journal of Thoracic and Cardiovascular Surgery 2016; 151(6): 1476-81.

24. Friedrich MG, Bougioukas I, Kolle J, Bireta C, Jebran FA, Placzek $M$, et al. NGAL expression during cardiopulmonary bypass does not predict severity of postoperative acute kidney injury. BMC Nephrology 2017; 18(1): 73.

25. De Loor J, Herck I, Francois K, Van Wesemael A, Nuytinck L, Meyer E, et al. Diagnosis of cardiac surgery-associated acute kidney injury: differential roles of creatinine, chitinase 3 -like protein 1 and neutrophil gelatinase-associated lipocalin: a prospective cohort study. Annals of Intensive Care 2017; 7(1): 24. 
26. Metzger J, Mullen W, Husi H, Stalmach A, HergetRosenthal S, Groesdonk HV, et al. Acute kidney injury prediction in cardiac surgery patients by a urinary peptide pattern: a case-control validation study. Critical Care (London, England) 2016; 20(1): 157.

27. Vandenberghe W, De Loor J, Hoste EA. Diagnosis of cardiac surgery-associated acute kidney injury from func- tional to damage biomarkers. Current opinion in anaesthesiology 2017; 30(1): 66-75.

28. Bulluck H, Maiti R, Chakraborty B, Candilio L, Clayton T, Evans $R$, et al. Neutrophil gelatinase-associated lipocalin prior to cardiac surgery predicts acute kidney injury and mortality. Heart (British Cardiac Society) 2017; doi: 10.1136/heartjnl-2017-311760.

Received: April 4, 2018

Accepted: April 25, 2018 